Article

\title{
Dynamics and Regulations of BimEL Ser65 and Thr112 Phosphorylation in Porcine Granulosa Cells during Follicular Atresia
}

\author{
Feng Yang, Yanhong Chen, Qiang Liu, Shizhen Dai and Shenming Zeng * \\ National Engineering Laboratory for Animal Breeding, Key Laboratory of Animal Genetics and Breeding of the \\ Ministry of Agriculture, College of Animal Science and Technology, China Agricultural University, \\ Beijing 100083, China; yangcfeng@cau.edu.cn (F.Y.); chenyanhong2017@outlook.com (Y.C.); \\ liuqiangtaian2008@163.com (Q.L.); daishizhen34@163.com (S.D.) \\ * Correspondence: zengsm@cau.edu.cn
}

Received: 27 December 2019; Accepted: 5 February 2020; Published: 10 February 2020

\begin{abstract}
BimEL protein is involved in follicular atresia by regulating granulosa cell apoptosis, but the dynamic changes of BimEL phosphorylation during follicular atresia are poorly understood. The aim of this study was to explore the changes of key BimEL phosphorylation sites and their upstream regulatory pathways. First, the levels of BimEL-Ser65 and BimEL-Thr112 phosphorylation (p-BimEL-S65, p-BimEL-T112) in granulosa cells (GC) from healthy (H), slightly-atretic (SA), and atretic (A) follicles and in cultured GC after different treatments were detected by Western blotting. Next, the effects of the corresponding site mutations of BIM on apoptosis of GC were investigated. Finally, the pathways of two phosphorylation sites were investigated by kinase inhibitors. The results revealed that p-BimEL-S65 levels were higher in GC from H than SA and A, whereas p-BimEL-T112 was reversed. The prosurvival factors like FSH and IGF-1 upregulated the level of p-BimEL-S65, while the proapoptotic factor, heat stress, increased the level of p-BimEL-T112 in cultured GC. Compared with the overexpression of wild BimEL, the apoptotic rate of the GC overexpressed BimEL-S65A (replace Ser65 with Ala) mutant was significantly higher, but the apoptotic rate of the cells overexpressing BimEL-T112A did not differ. In addition, inhibition of the ERK1/2 or JNK pathway by specific inhibitors reduced the levels of p-BimEL-S65 and p-BimEL-T112. In conclusion, the levels of p-BimEL-S65 and p-BimEL-T112 were reversed during follicular atresia. Prosurvival factors promote $\mathrm{p}$-BimEL-S65 levels via ERK1/2 to inhibit GC apoptosis, whereas proapoptotic factor upregulates the level of p-BimEL-T112 via JNK to induce GC apoptosis.
\end{abstract}

Keywords: BimEL phosphorylation; porcine; follicle atresia; granulosa cell; apoptosis

\section{Introduction}

Although follicle development is an ongoing process, atresia prevents follicles from ovulating to affect reproductive activity. In mammals, more than $99 \%$ of developing follicles undergo atresia [1-3]. It is widely accepted that ovarian follicular atresia is primarily caused by granulosa cell apoptosis [2], which is regulated by internal and external factors [4]. Two general pathways have been reported to be involved in apoptosis: survival factors withdrawal and bindings of specific dead ligands, such as tumor necrosis factor-alpha or Fas ligand, to their membrane receptors [5]. In mammalian ovarian follicles, granulosa cell apoptosis is triggered when endocrine and/or intrafollicular survival factors are inadequate, particularly gonadotropins and some growth factors [6,7]. According to a recent transcriptome analysis on porcine follicular atresia, DKK3, GADD45A, CAMTA2, CCDC80, DAPK2, ECSIT, MSMB, NUPR1, RUNX2, SAMD4A, and ZNF628 having a fold-change higher than five between healthy and atretic follicle granulosa cells could likely serve as markers of pig follicular atresia [7]. 
The let-7 miRNA family can also be related to granulosa cell programmed death, and let-7a/b/c/i may target TP53, CASP3, and FAS to prevent apoptosis, while let-7g may induce apoptosis by binding to CCND2 or Bcl-XL [8].

The Bcl-2 protein family plays irreplaceable roles during apoptosis, and one of the most important proteins is the BH3-only protein, Bim. Bim binds with high affinity to antiapoptotic Bcl-2 family members and regulates apoptotic signaling through Bax and Bak [9]. The gene encoding the Bim protein can be translated into a variety of homologs, including BimEL, BimL, and BimS, among which BimEL is the most abundant in cells [10]. BimEL has at least eight phosphorylation sites, which endow its different functions [10,11]. For example, the phosphorylation of BimEL at Ser65 is required for rapid dissociation of BimEL/Mcl-1 and BimEL/Bcl-xL complexes [12], which may play a vital role in BimEL degradation via the proteasome pathway to promote cell survival [13-15]. The stress kinase JNK can phosphorylate BimL at Thr56 and BimEL at Ser100, Thr112, and Ser114, which reduces the binding of BimEL to DLC1 (dynein light chain 1), leading to cell apoptosis [16-19]. Our recent results demonstrated that heat stress promotes BimEL phosphorylation through the JNK pathway and decreases the level of aromatase in porcine granulosa cells to damage follicular development [20]. Our prevous work also showed that IGF-1, insulin, and melatonin could phosphorylate and downregulate BimEL protein level, which can inhibit apoptosis of porcine granulosa cell [13,21,22].

During the process of follicular atresia, the level of BimEL protein in porcine granulosa cells is elevated [23], but the BimEL phosphorylation profile in granulosa cells is unknown during this process. In this experiment, the dynamics and regulations of BimEL, Ser65, and Thr112 phosphorylation during follicular atresia in porcine granulosa cells are pursued. The aim of this study was to decipher the roles of BimEL phosphorylation during porcine follicular atresia.

\section{Materials and Methods}

\subsection{Classification of Healthy, Slightly Atretic, and Atretic Follicles and Recovery of Granulosa Cells}

The ovaries from gilts aged about 5 months old were collected at a local abattoir and transported to the laboratory in a vacuum flask $\left(30-35{ }^{\circ} \mathrm{C}\right)$ containing sterile physiological saline within $2 \mathrm{~h}$. Ovaries were washed twice with sterile physiological saline $\left(37^{\circ} \mathrm{C}\right)$ containing $100 \mathrm{IU} / \mathrm{L}$ penicillin and $50 \mathrm{mg} / \mathrm{L}$ streptomycin. Healthy, slightly atretic, and atretic follicles were classified according to previously established morphological criteria $[7,8,23,24]$. Briefly, healthy follicles were defined as vascularized theca internal and clear amber follicular fluid with no debris. The follicles lacking any of these criteria were classified as atretic. The slightly atretic and atretic follicles had gray theca internal and flocculent follicular fluid in varying degrees. Follicular contents were punctured by hypodermic needle, and cumulus-oocyte complex and ovarian tissue were discarded under a stereo microscope. Granulosa cells were harvested by centrifuging.

\subsection{Granulosa Cell Culture and Experimental Design}

Porcine granulosa cells were cultured as previously described $[8,13,23]$. Briefly, the granulosa cells from healthy follicles (2-5 $\mathrm{mm}$ in diameter) were isolated by puncturing follicles with a 25-gauge hypodermic needle. The granulosa cell masses were recovered by pipette under stereoscope and cultured in DMEM/F12 supplemented with $100 \mathrm{IU} / \mathrm{L}$ penicillin and $50 \mathrm{mg} / \mathrm{L}$ streptomycin after washing thrice for different treatments. The cells that were suspended during culture in this media were defined as primary granulosa cells. To obtain adherent monolayer granulosa cells, the cells were gently washed thrice and then cultured in DMEM/F12 supplemented with 10\% fetal bovine serum (FBS), 100 IU/L penicillin, and $50 \mathrm{mg} / \mathrm{L}$ streptomycin at $37^{\circ} \mathrm{C}$ in humidified air with $5 \% \mathrm{CO}_{2}$ for $24 \mathrm{~h}$. The cells were passaged upon reaching confluence. Granulosa cells from about 10 ovaries can be selected and cultured in 10 dishes with a diameter of $35 \mathrm{~mm}$ as primary granulosa cells, and the same amounts of cells cultured in 4 dishes with a diameter of $100 \mathrm{~mm}$ as adherent granulosa cells. 
Figure 1 outlines the whole design of this experiment. Experiment I: Both levels of p-BimEL S65 and p-BimEL T112 in the granulosa cells from healthy, slightly-atretic, and atretic follicles were compared. Experiment II: The effects of proapoptotic factor (heat stress) and prosurvival factors (serum, FSH, and IGF-1) were observed on the levels of p-BimEL S65 and p-BimEL T112. Primary granulosa cell masses were treated with $10 \%$ FBS, FSH $(0.01 \mathrm{IU} / \mathrm{mL})$, or IGF-1 $(100 \mathrm{ng} / \mathrm{mL})$ for $24 \mathrm{~h}$. Heat stress was carried out according to the description in a previous study [25]. Briefly, the primary granulosa cells masses were incubated at $42{ }^{\circ} \mathrm{C}$ in humidified air with $5 \% \mathrm{CO}_{2}$ for $12 \mathrm{~h}$. Both levels of p-BimEL S65 and p-BimEL T112 were compared among different treatments. Experiment III: The effects of phosphorylation at Ser65 and Thr112 were observed during apoptosis in porcine granulosa cells. BimEL and BimEL mutation vectors were constructed and transfected into porcine granulosa cells. The levels of recombinant Bim proteins and morphological changes of granulosa cells were compared among the cells transfected by different vectors. The apoptotic rates were examined by flow cytometry. Experiment IV: The potential pathways were suggested to induce the levels of p-BimEL S65 and p-BimEL T112 by the prosurvival or proapoptotic factors.

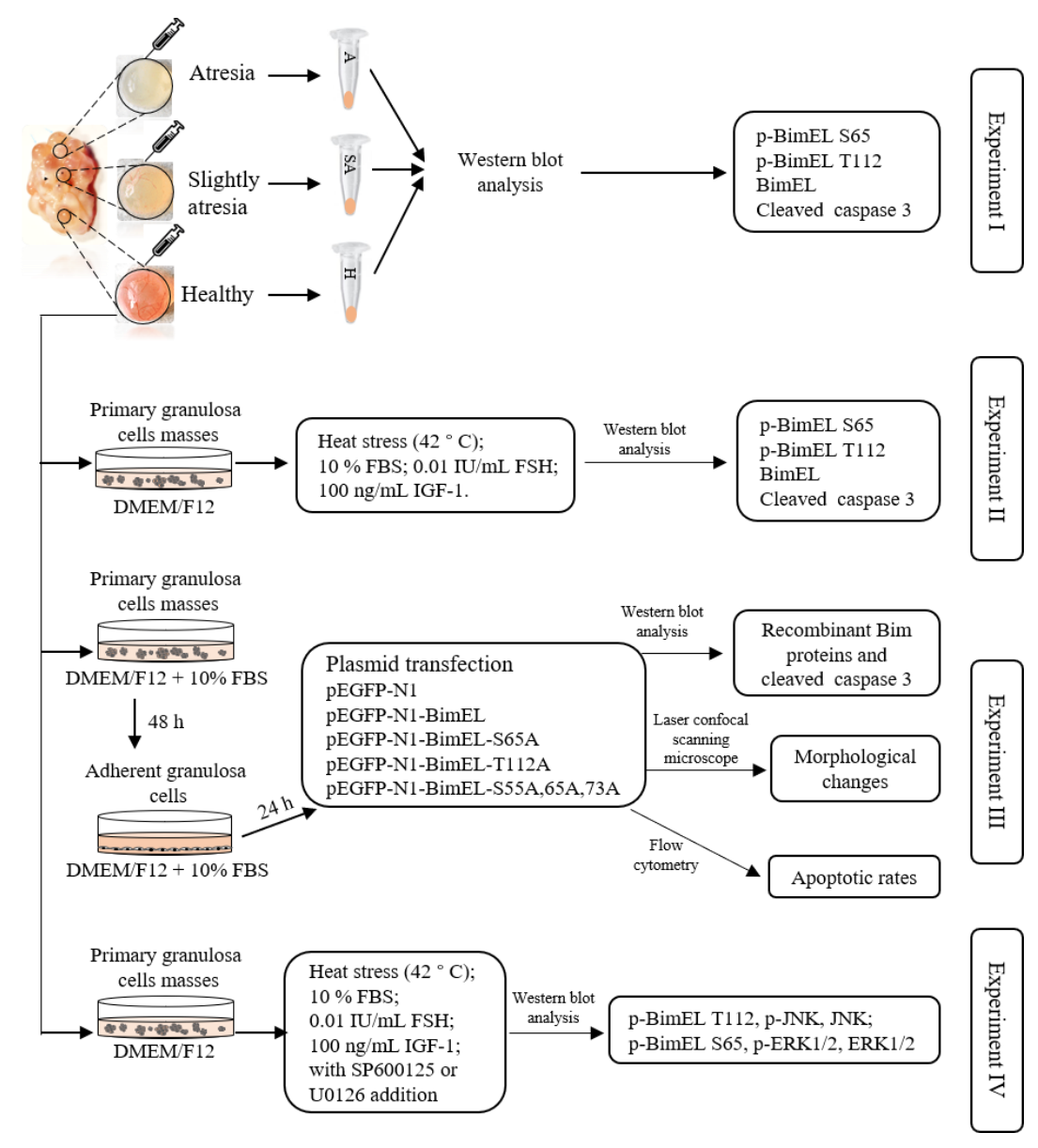

Figure 1. The workflow schematic of this study. Experiment I: Both levels of p-BimEL S65 and p-BimEL T112 in the granulosa cells from healthy, slightly-atretic, and atretic follicles were compared. Experiment II: The effects of proapoptotic factor (heat stress) and prosurvival factors (serum, FSH, and IGF-1) were observed on the levels of p-BimEL S65 and p-BimEL T112. Experiment III: The effects of phosphorylation at Ser65 and Thr112 were observed during apoptosis in porcine granulosa cells. Experiment IV: The potential pathways were suggested to induce the levels of p-BimEL S65 and p-BimEL T112 by the prosurvival or proapoptotic factors. Primary granulosa cells masses $=$ granulosa cells recovered from follicles; adherent granulosa cells $=$ monolayer adherent granulosa cells after in vitro culture. 


\subsection{Construction of BIM DNA Mutant Vectors and Transfection}

The PCR-amplified full-length porcine BimEL cDNA was constructed into pEGFP-N1 (Clontech). The reading frame of BimEL cDNA was connected with enhanced GFP to obtain a recombinant pEGFP-N1-BimEL plasmid. The plasmid was propagated using Trans1-T1 (Transgen Biotech, Beijing, China) as the host strain and purified with a Plasmid MiniPrep Kit (EM111-01, Transgen Biotech), followed by sequencing to confirm the open reading frame. Mutations of BimEL phosphorylation sites were performed by a Fast Mutagenesis System (FM111, Transgen Biotech), and primers for mutations were designed according to the manufacturer's instructions. Primers used in this experiment are shown in Table 1. Based on the pEGFP-N1-BimEL plasmid, porcine BimEL Ser 65 was mutated to alanine (BimEL-S65A), Thr 112 to alanine (BimEL-T112A), and Ser 55/65/73 to alanine (BimEL-S55A65A73A).

Table 1. Primers used to amplify pig BimEL and BimEL mutation.

\begin{tabular}{|c|c|c|}
\hline Name & & Primer Sequence \\
\hline \multirow{2}{*}{ BimEL } & Forward & gaattcatggcaaagcaaccttccgatg \\
\hline & Reverse & ggatccgcaatgtaagggggagggagggt \\
\hline \multirow{2}{*}{ BimEL-S65A } & Forward & ccactggcccaccgaccGCCcctggcccetttgctacc \\
\hline & Reverse & GGCggtcggtggggccagtgggccetgggggctgccttg \\
\hline \multirow{2}{*}{ BimEL-T112A } & Forward & aaatcaacacaaGCCccaagtcctccttgccaagcc \\
\hline & Reverse & acttggGGCttgtgttgatttgtcacaactcatggg \\
\hline \multirow{4}{*}{ BimEL-S55 ${ }^{\mathrm{A}} 65^{\mathrm{A}} 73^{\mathrm{A}}$} & S55A-Forward & gaccgctgccccaaggcGCCcccagggccactg \\
\hline & S55A-Reverse & GGCgccttgggggcagcggtccecttctccttccgg \\
\hline & S73A-Forward & tggcccetttgctaccagaGCCccgcttttcatcttcgtg \\
\hline & S73A-Reverse & GGCtctggtagcaaaggggccaggggcggtcggtgg \\
\hline
\end{tabular}

NucleofectorTM 2b Device (Lonza, AAB-1001, Cologne, Germany) and Basic Nucleofector ${ }^{\mathrm{TM}}$ Kit for Primary Mammalian Fibroblasts (Lonza, VPI-1002, Cologne, Germany) were used for plasmid transfection. The transfection protocol followed the manufacturer's instruction. Briefly, monolayer adherent granulosa cells were harvested after reaching confluence and divided into 6 equal parts (about $2 \times 10^{6}$ cells each) named as $\mathrm{CN}$ (with no plasmid but treated the same with other groups), vector (pEGFP-N1 transfection), BimEL (pEGFP-N1-BimEL transfection), BimEL-S65A (pEGFP-N1-BimEL-S65A transfection), BimEL-T112A (pEGFP-N1-BimEL-T112A transfection), and BimEL-S55A65A73A (pEGFP-N1-BimEL-S55A65A73A transfection). A total of $100 \mu$ L Nucleofector ${ }^{\mathrm{TM}}$ solution and $1.5 \mu \mathrm{g}$ plasmid DNA were added to each group except for the $\mathrm{CN}$; then, the cuvette with cell/DNA suspension was inserted into the Nucleofector ${ }^{\mathrm{TM}}$ Cuvette Holder to carry out the Nucleofector ${ }^{\mathrm{TM}}$ Program V-024 individually. After that, a total of $600 \mu \mathrm{L}$ of DMEM media were added into each group, and the samples were transferred immediately into six-well plate (final volume $2.0 \mathrm{~mL}$ media per well). Finally, the cells were cultured for $24 \mathrm{~h}$ or $48 \mathrm{~h}$ in humid air with $5 \% \mathrm{CO} 2$ at $37^{\circ} \mathrm{C}$ for further analysis.

\subsection{Observation of Cell Morphologies in Porcine Granulosa Cells after Transfection with Different BIM Mutant Vectors}

The granulosa cells were first transfected with BimEL, BimEL-S65A, BimEL-T112A, and BimEL-S55A65A73A vectors and cultured in cell slides with or without QVD-OPH (a general caspase inhibitor, HY-12305, MCE, Shanghai, China) treatments, respectively. After that, the cells were fixed with $4 \%$ paraformaldehyde, and the nuclei were stained with Hoechst 33342 . The samples were analyzed for morphological changes in cells and nuclei by a laser confocal scanning microscope (Nikon C1 standard detector, Nikon, Japan). 


\subsection{Protein Extraction and Immunoblotting}

The cells were harvested and washed once in PBS, then lysed on ice for 30 min with RIPA buffer (CST, 9806) and supplemented with 1\% (v/v) protease inhibitor Cocktail (HY-K0010) and 1\% $(v / v)$ phosphatase inhibitors (Cocktail I, HY-K0021; Cocktail II, HY-K0022; and Cocktail III, HY-K0023) purchased from MCE (MedChemExpress, Shanghai, China). Western blotting was performed as described previously [13]. Protein concentrations were determined by BCA protein assay kit (Transgen Biotech), and equal amounts of proteins (15-50 $\mu \mathrm{g} / \mathrm{lane})$ were separated by SDS-PAGE (12\% acrylamide running gel) and transferred to a nitrocellulose membrane (BioTrace ${ }^{\mathrm{TM}}$ NT, Pall Corp, FL, USA). The following antibody was used in this experiment: phospho-Bim (Thr56, Thr116) (PA5-64655, Thermo Fisher Scientific Shanghai, China); phospho-Bim (Ser69) (4581), p-JNK (9251S), p-ERK1/2 (9101S), cleaved caspase 3 (9664S), and Bim (C34C5) were all purchased from Cell Signaling Technology (Shanghai, China); ERK1/2 (abs130092), JNK1/2 (abs131832), and Actin (abs132001) were purchased from Absin (Shanghai, China). The Western blotting images were processed using Image J software (National Institutes of Health, Bethesda, MD, USA). The antibodies were diluted at the recommended ratio with Beyotime (P0256, Shanghai, China) diluent.

\subsection{Histology}

Porcine ovaries ( $2-5 \mathrm{~mm}$ in diameter) were fixed overnight in $4 \%$ phosphate-buffered formaldehyde at $4{ }^{\circ} \mathrm{C}$ for 7 days and then embedded in paraffin. Randomly selected sections ( $5 \mu \mathrm{m}$ each) were used for subsequent Hematoxylin-eosin, TUNEL, and immunohistochemical analyses. Hematoxylin and eosin were purchased from Solarbio (Beijing, China).

Apoptosis was analyzed by TUNEL (In Situ Cell Death Detection Kit, TMR red, Roche, Shanghai, China) according to the manufacturer's protocol. Briefly, after deparaffinization and rehydration, sections were incubated with proteinase- $\mathrm{K}(20 \mathrm{~g} / \mathrm{mL})$ for $15 \mathrm{~min}$ at room temperature and quenched in $3 \% \mathrm{H}_{2} \mathrm{O}_{2}$ in PBS for $10 \mathrm{~min}$ (to block endogenous peroxidase). They were then incubated in a humidified chamber with equilibration buffer for $5 \mathrm{~min}$ and finally incubated with terminal deoxynucleotidyl transferase for $1 \mathrm{~h}$ at $37^{\circ} \mathrm{C}$. Negative control slides were incubated as described above, without the final addition of terminal deoxynucleotidyl transferase. After TUNEL reactions were complete, slides were washed in PBS, sealed under coverslips with nail varnish and examined under fluorescence microscopy.

Immunohistochemical analysis was performed as previously described [23]. Briefly, phospho-Bim (Ser69), 1:200, was used to detect porcine phospho-Bim-Ser65 expression. HRP-conjugated anti-rabbit antibody (1:100, Zhongshan Biotechnology, Beijing, China) was applied for $1 \mathrm{~h}$ at room temperature. The binding of primary antibody was visualized using diaminobenzidine for $3-5 \mathrm{~min}$. The phosphoBim-Ser65 labeling was examined using a Leica microscope, and images were recorded (Leica DC 200 digital camera; Leica, Wetzlar, Germany).

\subsection{Apoptosis Assay by Fluorescence-Activated Cell Sorter}

QVD-OPH $(20 \mu \mathrm{M})$ was added immediately after transfection. After $24 \mathrm{~h}$, QVD-OPH was withdrawn by changing the culture media, and another $24 \mathrm{~h}$ later, the cells were harvested and stained with PE-conjugated Annexin V and 7-AAD in a binding buffer for $15 \mathrm{~min}$ as described previously [26,27]. GFP-positive cells were gated for apoptosis analysis by a fluorescence-activated cell sorter (FACS, Becton Dickinson, Franklin Lakes, NJ, USA), and the data were analyzed by FlowJo_V10 software. 


\subsection{Statistical Analyses}

All data are presented as the mean \pm SD and were analyzed using a one-way ANOVA with SPSS 22 (IBM, SPSS, Chicago, IL, USA) for Windows. The ANOVA followed by a post hoc Dunnett's test was used to determine significant differences between different groups. Differences were considered statistically significant at $p<0.05$.

\section{Results}

\subsection{Subsection}

3.1.1. The levels of P-BimEL-S65 were Decreased while P-BimEL-T112 were Increased in Granulosa Cells during Follicular Atresia

To confirm the follicular status identified by the morphology criteria, HE staining was performed in healthy, slightly-atretic, and atretic follicles. The results showed that all granulosa cells tightly lined the basement membrane in healthy follicles, but cells began to diffuse away from the basement membrane in slightly atretic follicles. More seriously, the cells drifted to the follicular antrum in the atretic follicles (Figure 2A). Furthermore, granulosa cells in healthy follicles rarely showed TUNEL signal, while slightly atretic and atretic follicles exhibited strong apoptotic signals (Figure 2B). The changes of p-BimEL S65, p-BimEL T112, and other related proteins in granulosa cells from porcine healthy, slightly atretic, and atretic follicles were analyzed by Western blotting. The results showed that the level of p-BimEL S65 was higher, while the level of p-BimEL T112 was lower in healthy follicles than in atretic ones. Conversely, p-BimEL S65 was lower, while the level of p-BimEL T112 was more highly expressed in atretic follicles compared with the healthy ones (Figure 2C). In addition, the levels of three Bim isoforms (BimEL, BimL, and BimS) and cleaved caspase-3 were all higher in slightly atretic and atretic follicles than those in healthy follicles. Immunohistochemical results of porcine ovarian tissue further confirmed that the expression profile of p-BimEL-S65 was similar to the above results (Figure 2D). 
A

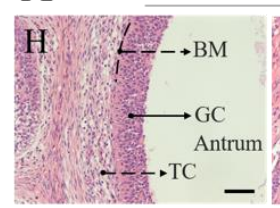

HE staining

B
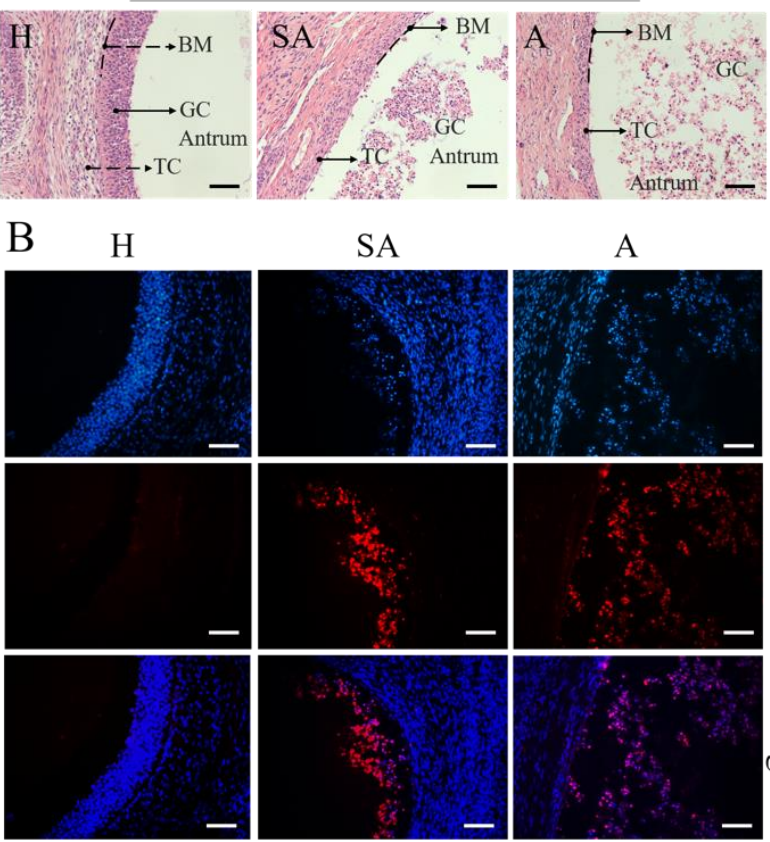

SA
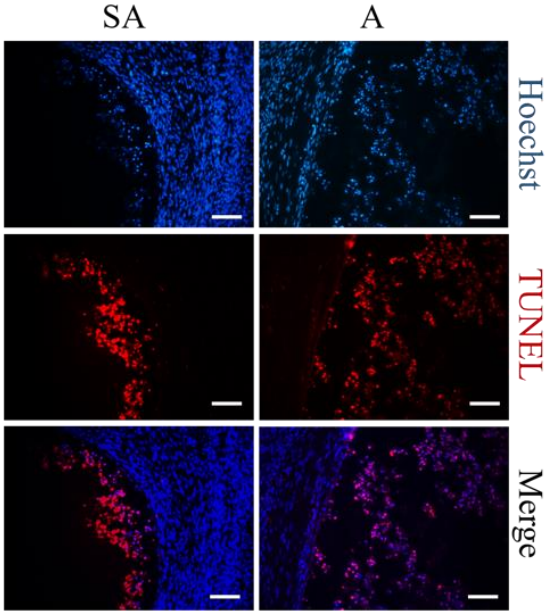

$\mathrm{D}$ IHC: anti-pBimEL-S65
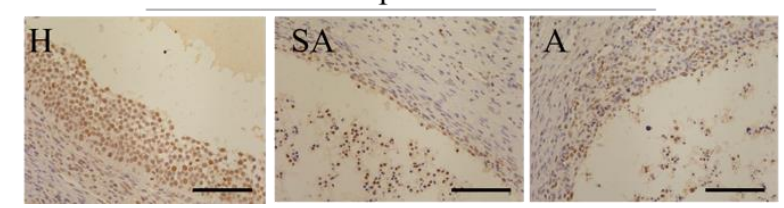

$\mathrm{C}$
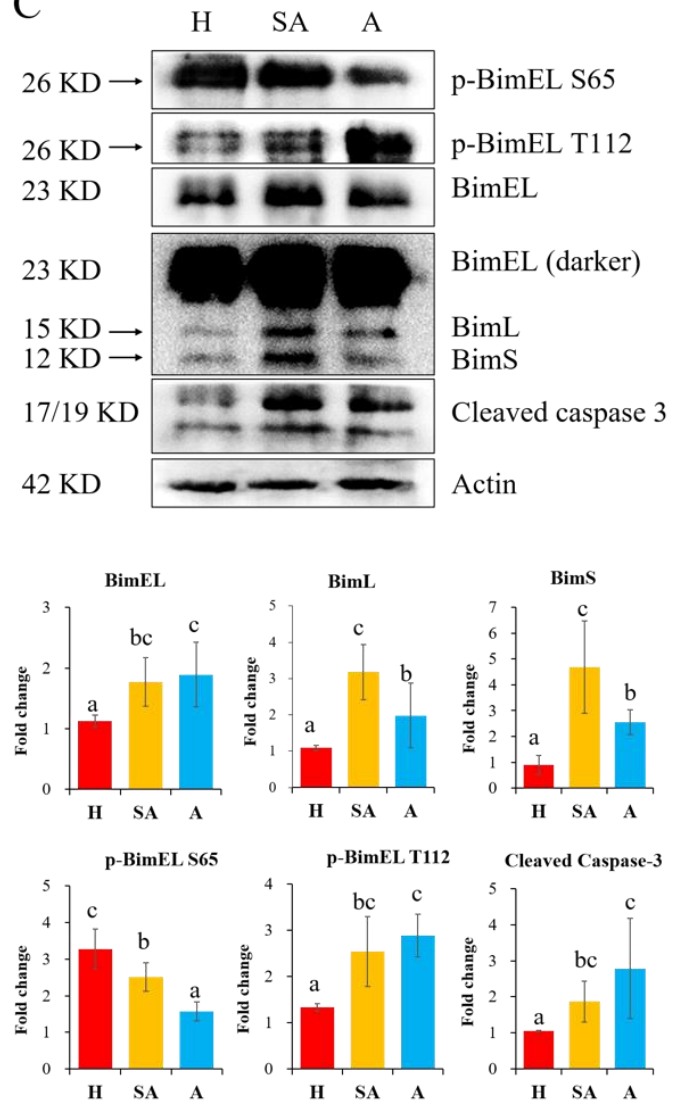

Figure 2. Levels of p-BimEL-S65 were decreased while p-BimEL-T112 were increased in granulosa cells during follicular atresia. (A) Hematoxylin-eosin (HE) staining of porcine healthy, slightly atretic and atretic follicle. Scale bar $=100 \mu \mathrm{m}$. BM = basement membrane, $\mathrm{GC}=$ granulosa cell, $\mathrm{TC}=$ theca cell. (B) Hoechst and TUNEL staining of follicles with different status. Scale bar $=100 \mu \mathrm{m}$. (C) Granulosa cells obtained from porcine healthy, slightly atretic, and atretic follicles were analyzed by Western blotting. Actin is the loading control. Column charts show the quantitative analysis of p-BimEL S65, p-BimEL T112, BimEL, BimL, BimS, and cleaved caspase-3. The data are representative of three independent experiments. Values are expressed as the means \pm SD of three separate experiments. The bars are labeled with completely different letters indicating significant difference, $p<0.05$. (D) p-BimEL-S65 protein was localized with specific antibodies by immunohistochemistry (IHC). Scale bar $=100 \mu \mathrm{m}$. H healthy follicle; SA = slightly-atretic follicle; A = atretic follicle, p-BimEL S65 = phosphor-BimEL-Ser65; p-BimEL $\mathrm{T} 112=$ phosphor-BimEL-Thr112.

3.1.2. Effects of Proapoptotic and Survival Factors on the Levels of P-BimEL S65 and P-BimEL T112 in Cultured Granulosa Cells

Proapoptotic factors like heat stress in summer may induce granulosa cell apoptosis and cause follicular atresia, while prosurvival factors like FSH and IGF-1 can promote granulosa cell survival and proliferation. Therefore, the effects of these factors on the levels of p-BimEL S65 and p-BimEL T112 in granulosa cells were investigated. Porcine primary granulosa cells were cultured in vitro and treated with proapoptotic (heat stress) or survival factors (serum supply, IGF-1, and FSH), and the levels of p-BimEL S65, p-BimEL T112, and other related proteins were detected (Figure 3A). The results showed that the level of BimEL in granulosa cells was decreased after heat stress, FSH, and IGF-1 treatment compared with the $\mathrm{CN}$ and serum treatment groups. The levels of p-BimEL S65 were elevated after IGF-1 and FSH treatments compared with the $\mathrm{CN}$ and heat stress (Figure 3B). The level of p-BimEL $\mathrm{T} 112$ was raised after $12 \mathrm{~h}$ of heat stress at $42{ }^{\circ} \mathrm{C}$ (Figure 3B) compared with the $\mathrm{CN}$ and the prosurvival 
factor treatment groups. The level of cleaved caspase-3 was decreased after the serum, IGF-1, and FSH treatments compared with the $\mathrm{CN}$ (Figure 3B).
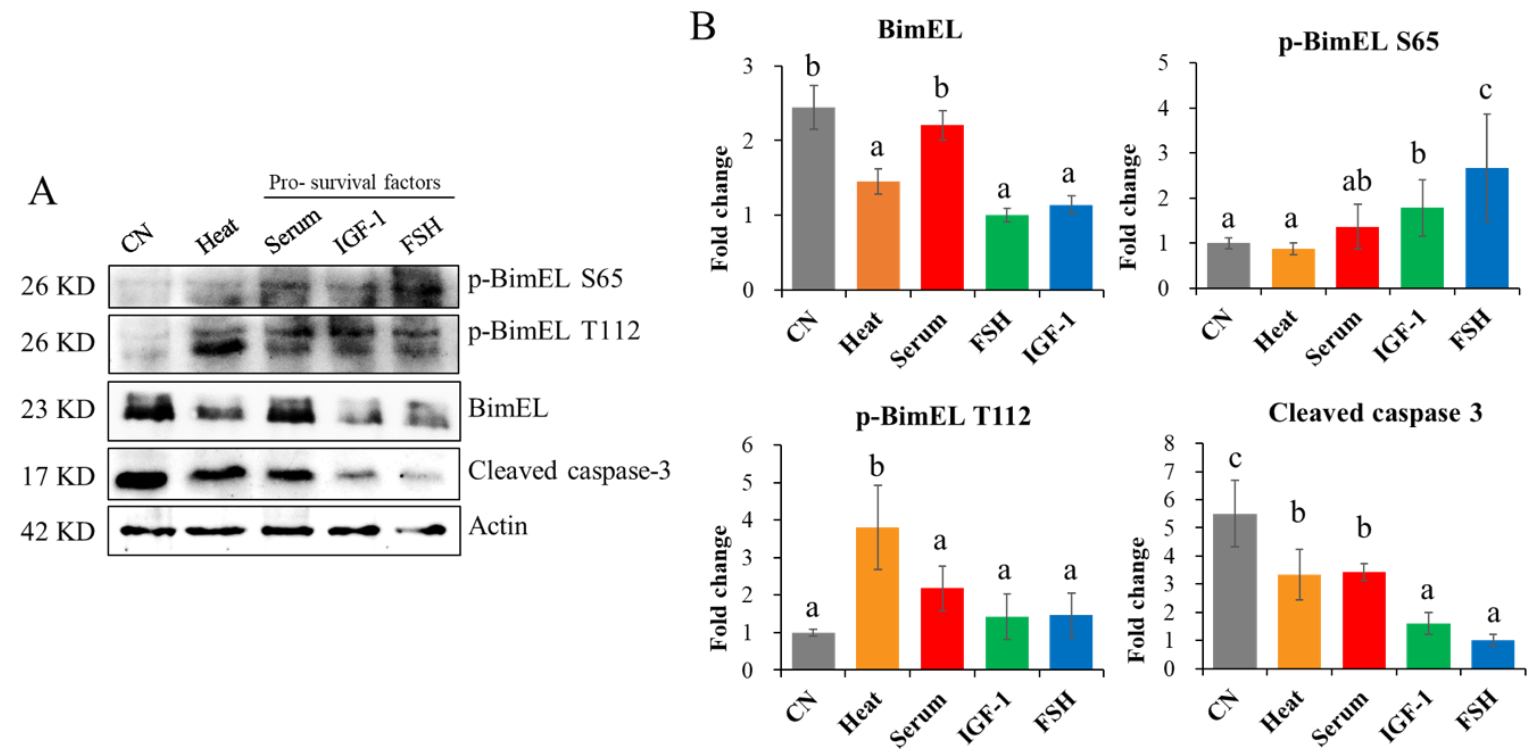

Figure 3. Effects of proapoptosis and prosurvival factors on the levels of p-BimEL S65, p-BimEL T112, and other related proteins in cultured granulosa cells.(A) Protein levels of porcine primary granulosa cells treated with heat stress, serum, IGF-1 or FSH. CN = cultured without treatment; Heat = heat stress treatment at $42{ }^{\circ} \mathrm{C}$ for $12 \mathrm{~h}$; serum $=10 \%$ fetal bovine serum treatment for $24 \mathrm{~h}$; IGF-1 = treated with $100 \mathrm{ng} / \mathrm{mL}$ IGF-1 for $24 \mathrm{~h}$; FSH = treated with $0.01 \mathrm{IU} / \mathrm{mL}$ FSH for $24 \mathrm{~h}$. (B) Quantitative analysis of BimEL, p-BimEL S65, p-BimEL T112, and cleaved caspase-3. p-BimEL S65 = phosphor-BimEL-Ser65; p-BimEL T112 $=$ phosphor-BimEL-Thr112. Values are expressed as the means \pm SD of three separate experiments. The bars labeled with completely different letters indicate significant difference, $p<0.05$.

\subsubsection{Effects of BimEL Phosphorylation Site Mutation on the Apoptosis of Porcine Granulosa Cells}

To further study effects of the two key sites of phosphorylation in BimEL on granulosa cells, BimEL and BimEL phosphorylation site mutation plasmids were constructed. The plasmids of wild-type BimEL, BimEL-S65A, BimEL-T112A, or BimEL-S55 ${ }^{\mathrm{A}} 65^{\mathrm{A}} 73^{\mathrm{A}}$ were transfected into porcine granulosa cells with about $30 \%$ efficiency. The results demonstrated that BimEL-GFP and BimL-GFP in the four transfections were all expressed, while endogenous Bim expression levels did not change compared with the pEGFP-N1 vector and transfection control (CN) (Figure 4A and B-1). Notably, levels of cleaved caspase 3 were elevated in the four groups (Figure 4B-2).

After $24 \mathrm{~h}$ of transfection, the green positive cells were seldom found in the groups transfected with BimEL, BimEL-S65A, BimEL-T112A, and BimEL-S55 ${ }^{\mathrm{A}} 65^{\mathrm{A}} 73^{\mathrm{A}}$ plasmids compared to those in the pEGFP-N1 vector. Moreover, the positive cells were almost wrinkled with fragmented or shrunk nuclei (Figure 4C-1). However, the amount of positive green cells increased in BimEL and its mutant groups when the cells were treated with $20 \mu \mathrm{M}$ QVD-OPH (inhibitor of apoptosis) for $24 \mathrm{~h}$ immediately after transfection, and most green cells displayed normal morphologies (Figure 4C-2). After $24 \mathrm{~h}$ of QVD-OPH withdrawal, most green cells in BimEL and its mutant groups exhibited apoptosis, including cellular shrinkage, plasma membrane blebbing, and cellular or nuclear fragmentation (Figure 4C-3). 
A

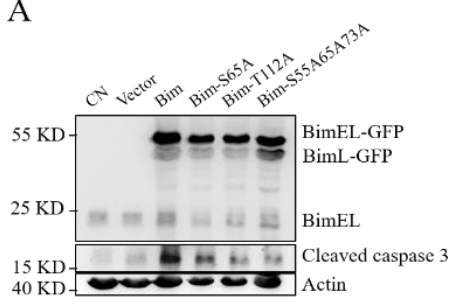

C

(1)

$0 \mu \mathrm{M}$ QVD-OPH

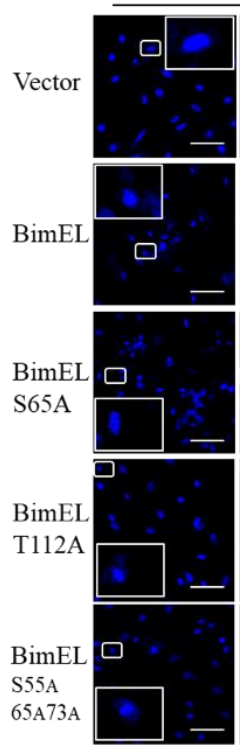

Hoechst

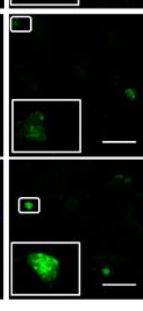

GFP
B

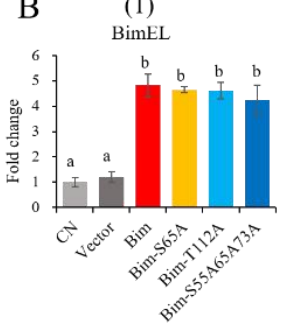

$20 \mu \mathrm{M}$ QVD-OPH
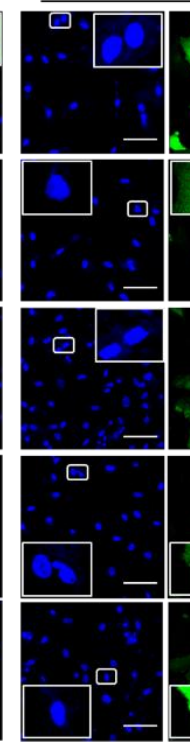

Hoechst
(2)

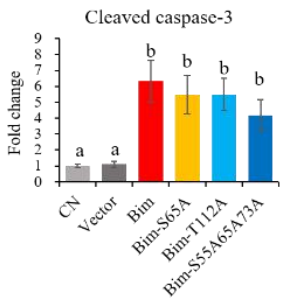

(2)
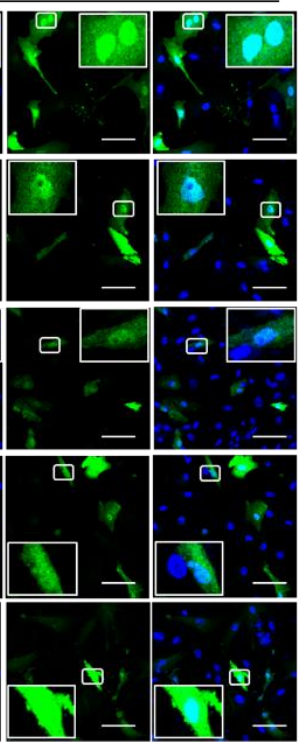

GFP

Merge

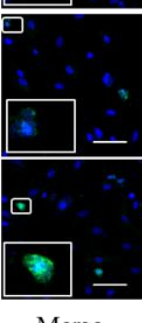

Figure 4. Effects of BimEL phosphorylation sites mutation on apoptosis of porcine granulosa cells. Porcine granulosa cells were transfected with vector (pEGFP-N1), BimEL (pEGFP-N1-BimEL), BimEL-S65A (pEGFP-N1-BimEL-S65A), BimEL-T112A (pEGFP-N1-BimEL-T112A),

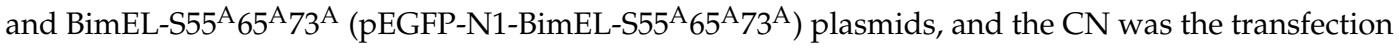
control. Values are expressed as means \pm SD from five independent experiments. The bars labeled with completely different letters indicate significant difference, $p<0.05$. (A) The levels of recombinant Bim-GFP proteins were compared among the porcine granulosa cells transfected with different plasmids. The cells were harvested for Western blot after transfection for $24 \mathrm{~h}$. (B) The results of quantitative analysis of BimEL (B-1) and cleaved caspase-3 (B-2) levels in different groups. (C) The treatment of QVD-OPH increased the numbers of green positive cells after transfection with BimEL and BimEL phosphorylation site mutations. The cells from each plasmid transfection were equally divided into three groups and were cultured in one slide. (C-1) The cells in the $0 \mu \mathrm{M}$ QVD-OPH (DMSO control). (C-2) The cells of $20 \mu \mathrm{M}$ QVD-OPH groups were cultured for $24 \mathrm{~h}$. The Cells (C-3) were cultured in the medium containing $20 \mu \mathrm{M}$ QVD-OPH for $24 \mathrm{~h}$ and then cultured in the same medium without QVD-OPH for another $24 \mathrm{~h}$. After culturing, the cells were fixed with $4 \%$ paraformaldehyde and stained with Hoechst 33342. The samples were analyzed with a laser confocal scanning microscope. Representative images are shown. Scale bar $=100 \mu \mathrm{m}$. Triangle indicates the fragmented or shrunk nuclei. Arrows point out the shrinkage cells. (D) Apoptotic rates of green positive cells after transfection with BimEL and BimEL with different phosphorylation site mutations. QVD-OPH $(20 \mu \mathrm{M})$ was administrated immediately after transfection. After $24 \mathrm{~h}, \mathrm{QVD}-\mathrm{OPH}$ was taken out, and the cells were harvested after an additional $24 \mathrm{~h}$ for Annexin $\mathrm{V}$ and 7-AAD staining, followed by flow cytometry analysis. The green positive cells were further analyzed for Annexin V and 7-AAD. The percentages of apoptotic cells (Annexin V positive) from each group were compared. 
Apoptotic rates of the cells transfected with BimEL, BimEL-S65A, BimEL-T112A, or BimEL$S 55^{\mathrm{A}} 65^{\mathrm{A}} 73^{\mathrm{A}}$ plasmids were compared by flow cytometry assay. The results demonstrated that apoptotic rates of cells in BimEL and its mutant groups were all higher than that of the pEGFP-N1 vector. Furthermore, BimEL-S65A and BimEL-S55 ${ }^{\mathrm{A}} 65^{\mathrm{A}} 73^{\mathrm{A}}$ groups had higher apoptotic rates than others, while BimEL-T112A had no difference with the BimEL group in apoptosis (Figure 4D).

\subsubsection{Regulations of P-BimEL S65 and P-BimEL T112 in Porcine Granulosa Cells}

Previous studies showed that BimEL could be phosphorylated at Ser65 by ERK1/2 [28] and at Thr112 by JNK [16]. To confirm whether p-BimEL S65 and p-BimEL T112 are regulated by ERK1/2 and JNK in granulosa cells, the porcine primary granulosa cells were treated by heat stress, FSH, and IGF-1 together with different specific inhibitors of cellular pathways. The present results show that heat stress increased both the levels of p-JNK and p-BimEL T112, but SP600125 prevented their changes. Similarly, FSH and IGF-1 treatments increased p-ERK1/2, p-BimEL S65, and total BimEL phosphorylation levels; however, U0126 could block these shifts (Figure 5). The results indicate that BimEL S65 and BimEL T112 can be phosphorylated by the ERK1/2 and JNK pathway, respectively, in porcine follicular granulosa cells.

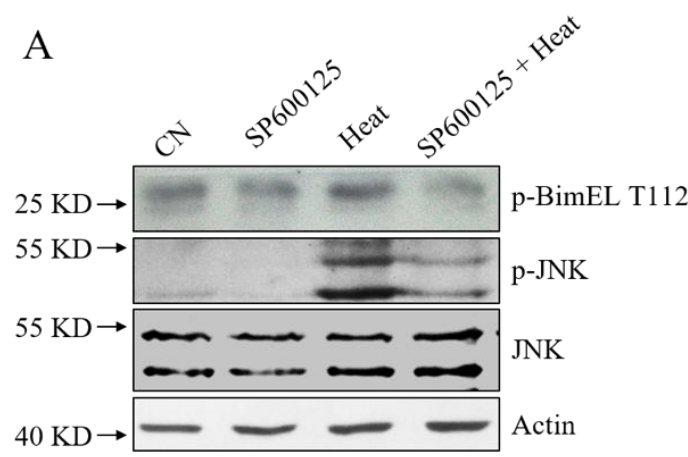

p-BimEL T112

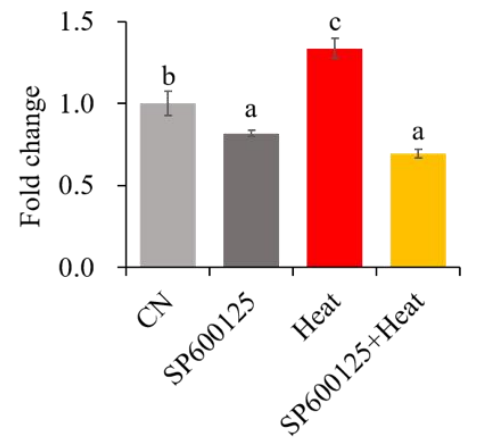

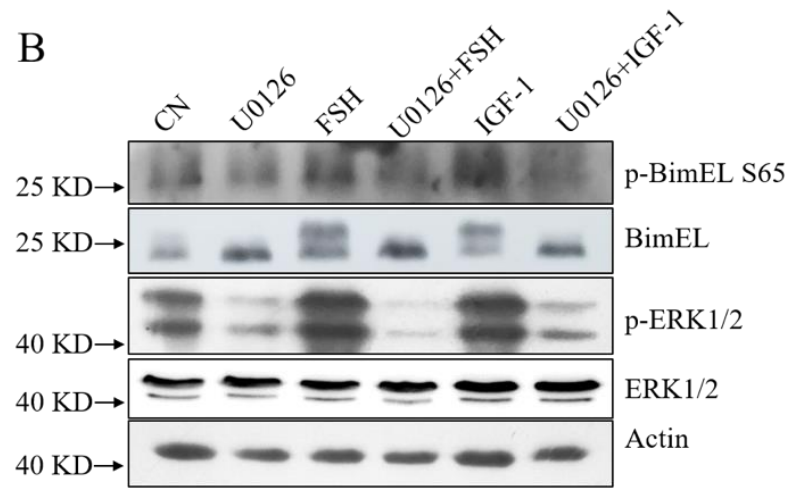

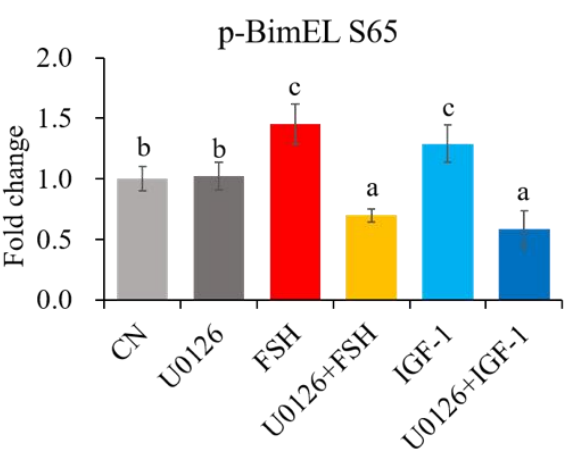

Figure 5. The possible pathways of p-BimEL S65 and p-BimEL T112 regulated by different factors in porcine granulosa cells. (A) The treatment of SP600125 blocked the increase of BimEL T112 phosphorylation induced by heat stress. (B) The treatment of U0126 hindered the increase of BimEL S65 phosphorylation induced by FSH or IGF-1. CN $=$ untreated, Heat $=$ heat stress at $42{ }^{\circ} \mathrm{C}$ for $12 \mathrm{~h}, \mathrm{IGF}-1$ = treated with $100 \mathrm{ng} / \mathrm{mL}$ IGF-1 for $24 \mathrm{~h}$, FSH = treated with $0.01 \mathrm{IU} / \mathrm{mL}$ FSH for $24 \mathrm{~h}$, U0126 = treated with $20 \mu \mathrm{M}$ U0126 for 24 h, SP600125 = treated with $20 \mu \mathrm{M}$ SP600125 for $12 \mathrm{~h}$; p-BimEL S65 = phosphor-BimEL-Ser65; p-BimEL T112 = phosphor-BimEL-Thr112. The cells were harvested, and equal amounts of proteins were used for immunoblotting. Values are expressed as the means \pm SD of three separate experiments. The bars labeled with completely different letters indicate significant difference, $p<0.05$. 


\section{Discussion}

Our results illustrate the dynamic changes of BimEL phosphorylation during porcine follicular atresia, and its biofunctions vary with phosphorylation sites regulated by different pathways. The survival factors induce phosphorylation at $\mathbf{S 6 5}$ and inhibit granulosa cell apoptosis through the ERK pathway, whereas the proapoptotic factor stimulates phosphorylation at T112, leading to granulosa cell apoptosis by the JNK pathway.

It is well-known that apoptosis of granulosa cells contributes to ovarian follicular atresia [29], and our previous research confirmed that the level of BimEL was higher in porcine atretic follicles than in healthy ones [23]. This study shows that the apoptotic granulosa cells detach from the basement membrane and enter the follicular antrum (Figure 2A,B). However, post-translational modification of BimEL in follicles is poorly understood. According to our current knowledge, this research is the first to examine the changes in BimEL phosphorylation sites during mammalian follicular atresia. Phosphorylation levels of BimEL at S65 and T112 are inversed in granulosa cells from healthy and atretic follicles. Immunohistochemical results of porcine ovarian tissue further confirmed the expression profile of p-BimEL-S65; however, anti-pBimEL-T112 antibody is not suitable for immunohistochemistry. A previous study on $\mathrm{K} 562$ cells reported that phosphorylation at $\mathrm{S} 65$ promoted degradation of BimEL to inhibit apoptosis [14], and BimEL degradation requires the ERK-dependent pathway $[14,15]$. Our recent research demonstrated that melatonin promotes ubiquitination of phosphorylated BimEL in porcine granulosa cells [13]. Nevertheless, phosphorylation at T112 promoted separation of BimEL from DCL8 to induce apoptosis [26]. Alternative splicing can delete sequences derived from exon 3 or exons 3 and 4 to create BimL and BimS, respectively. We showed that the two kinds of Bim isoform, BimL and BimS, exhibited the same pattern as BimEL in granulosa cells during follicular atresia. Although the relative expression levels of BimL and BimS were lower than BimEL, they too may also have strong apoptotic activity [30]. This suggests that these two splices may also be involved in the apoptosis of granulosa cells. Bim-targeting cancer therapies may provide more effective and unique tumor management modalities in the future [31]. For example, miR-25 can regulate apoptosis by targeting Bim in human ovarian cancer and may be a potential therapeutic target for ovarian cancer [32].

BimEL was first demonstrated to be a phospho-protein in IL-3-stimulated BaF3 cells [33]. BimEL in ovarian granulosa or other cells could be phosphorylated by proapoptotic factors like UV and heat stress [26] and also by survival factors such as IGF-1 [28,34], FSH [13,23], and melatonin [13]. Mammalian fertility is reduced during heat exposure in the summer because heat stress caused by high environmental temperature impairs folliculogenesis, leading to ovulation of low-quality oocytes [35]. Heat stress was also reported to alter follicular dynamics [36], steroidogenic ability [37], granulosa cell function [38], and oocyte maturation [39,40], which contributes to low reproductive efficiency in mammals during the summer [25]. Withdrawing serum was reported to induce neuronal cell and R28 cell apoptosis by increasing caspase-3/7 activity and promoting cleavage of caspase- 9 and $-3[28,41]$. Nevertheless, Bim $^{\mathrm{KO}}$ mouse embryonic fibroblasts are resistant to serum withdrawal-induced apoptosis [12]. However, limited information is available on the dynamics, functions, and regulations of its phosphorylation sites in granulosa cells during follicular atresia. In cultured granulosa cells, we found that heat stress could increase phosphorylation of BimEL at T112, while serum, FSH, or IGF-1 treatment promoted phosphorylation of BimEL at S65. Previous studies revealed that survival factors can phosphorylate BimEL at 565 through the ERK pathway $[14,18]$. In addition, we noticed that serum treated granulosa cells showed a higher level of cleaved caspase 3 than that in the FSH or IGF-1 groups, which indicated that serum may be not an eminent prosurvival factor.

In the present results, overexpression of BimEL or BimEL with different phosphorylation site mutations increased granulosa cells apoptosis in vitro, which is consistent with our previous results [23]. The levels of apoptosis were similar when the cells were transfected with BimEL or BimEL-T112A. These results agree with research on the 293T cell [26]. However, the apoptotic rate was increased when the serine at the 65th amino acid residue in BimEL was replaced by alanine to prevent its 
phosphorylation. This was consistent with reports that BimEL without phosphorylation of S55A, $\mathrm{S} 65 \mathrm{~A}$, and S100A had strong interactions with BAX to enhance its proapoptotic activity [42]. In this experiment, BimEL-S55 $65^{\mathrm{A}} 73^{\mathrm{A}}$ increased the apoptotic rate of porcine granulosa cells, which was consistent with the previous results from BimEL S55/65/73A mutant mice [11]. In mice, the mutation of $\mathrm{T} 112$ in the Bim gene decreased binding of Bim to the antiapoptotic protein $\mathrm{Bcl} 2$, increasing cell survival because the binding of $\mathrm{Bim}$ to $\mathrm{Bcl} 2$ contributes to Bim-induced apoptosis [43]. In contrast, mutation of the phosphorylation sites S55, S65, and S73 increased apoptosis because of reduced proteasomal degradation of Bim [11]. Although the three phosphorylation sites are implicated in the regulation of Bim stability, the S65 phosphorylation site may play a vital role in this process. Activated ERK1/2 binds to human BimEL via the DEF domain and phosphorylates Ser69 (same as pig BimEL Ser65), which in turn induces a conformational change allowing phosphorylation at a second site [18]. Phosphorylation at $\mathrm{S} 69$ can also promote phosphorylation at additional sites on Ser 93/94/98 by ribosomal S6 kinase (Rsk1/2) within a conserved phosphodegron motif recognized by the F-box protein beta-transducin repeat containing E3 ubiquitin-protein ligase ( $\beta \operatorname{TrCP})$ [44].

BimEL can be phosphorylated by several MAP kinases (including ERK, JNK, and p38 isoforms) to regulate its activity [11]. Previous research reported that the ERK1/2-dependent phosphorylation of BimEL promotes its rapid dissociation from Mcl-1 and Bcl-xL in CR1-11 cells. The dissociation of BimEL from Mcl-1 requires phosphorylation of BimEL at S65 through the ERK1/2 pathway [12]. IGF-1 was reported to induce BimEL phosphorylation through ERK1/2 in an R28 rat retinal neuronal precursor cell line [28]. Gliotoxin and the supernatant of Aspergillus fumigatus activated the JNK pathway to induce BimEL phosphorylation at S100, T112, and S114, causing apoptosis in mouse fibroblasts, alveolar epithelial cells, and human bronchioles [16]. Exposure to environmental stress, including UV radiation, caused JNK-dependent phosphorylation of BimEL in 293T cells [26]. Herein, we confirmed that p-BimEL S65 and p-BimEL T112 in follicular granulosa cells were also regulated by ERK1/2 and JNK, respectively.

Based on our results, a hypothetical model of BimEL phosphorylation participating in animal follicular atresia is presented in Figure 6. In the antral follicles, survival factors like FSH and IGF-1 promote phosphorylation of BimEL S65 via the ERK pathway inhibiting granulosa cell apoptosis, and, therefore, could prevent follicular atresia. Nevertheless, harmful factors like heat stress or insufficient growth factors will stimulate the phosphorylation of BimEL T112 via the JNK pathway inducing granulosa cell apoptosis, and contribute to follicular atresia. The present results increased our knowledge about the role of BimEL phosphorylation during follicular atresia. Moreover, it may be helpful in improving efficiency of assisted reproductive technologies and treatment of infertility caused by ovarian dysplasia.

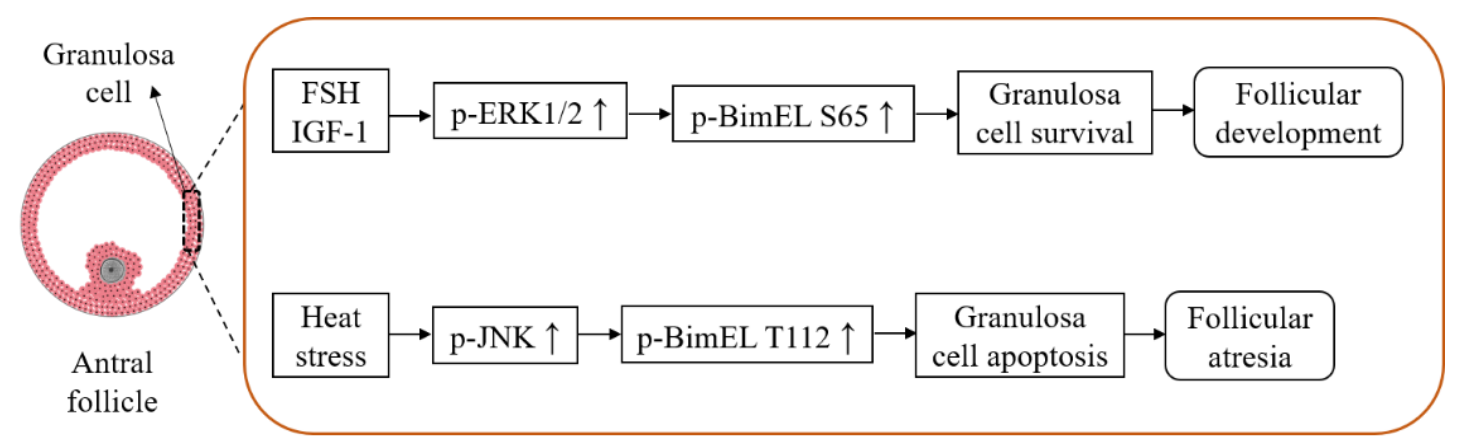

Figure 6. Hypothetical model of functions and regulations of p-BimEL S65 and p-BimEL T112 during follicular atresia.

Author Contributions: Methodology, F.Y. and Q.L.; software, F.Y.; validation, F.Y., Q.L., and S.Z.; investigation, F.Y., Y.C., and S.D.; writing — original draft preparation, F.Y.; writing—review and editing, F.Y. and S.Z.; visualization, 
S.Z.; supervision, S.Z.; project administration, S.Z.; funding acquisition, S.Z. All authors have read and agreed to the published version of the manuscript.

Funding: This work was supported by grants from National Natural Science Foundation of China $(31672419,31470077)$.

Acknowledgments: We thank Qiuyan Li for her support in cell transfection. We thank LetPub (www.letpub.com) for its linguistic assistance during the preparation of this manuscript.

Conflicts of Interest: The authors declare no conflict of interest.

\section{References}

1. Hughes, F.M., Jr.; Gorospe, W.C. Biochemical identification of apoptosis (programmed cell death) in granulosa cells: Evidence for a potential mechanism underlying follicular atresia. Endocrinology 1991, 129, 2415-2422. [CrossRef] [PubMed]

2. Tilly, J.L.; Kowalski, K.I.; Johnson, A.L.; Hsueh, A.J. Involvement of apoptosis in ovarian follicular atresia and postovulatory regression. Endocrinology 1991, 129, 2799-2801. [CrossRef] [PubMed]

3. Chun, S.Y.; Eisenhauer, K.M.; Minami, S.; Billig, H.; Perlas, E.; Hsueh, A.J. Hormonal regulation of apoptosis in early antral follicles: Follicle-stimulating hormone as a major survival factor. Endocrinology 1996, 137, 1447-1456. [CrossRef] [PubMed]

4. Hsueh, A.J.; Billig, H.; Tsafriri, A. Ovarian follicle atresia: A hormonally controlled apoptotic process. Endocr. Rev. 1994, 15, 707-724.

5. Guthrie, H.D.; Garrett, W.M. Apoptosis during folliculogenesis in pigs. Reprod. Suppl. 2001, 58, 17.

6. Scaramuzzi, R.J.; Baird, D.T.; Campbell, B.K.; Driancourt, M.-A.; Dupont, J.; Fortune, J.E.; Gilchrist, R.B.; Martin, G.B.; McNatty, K.P.; McNeilly, A.S.; et al. Regulation of folliculogenesis and the determination of ovulation rate in ruminants. Reprod. Fertil. Dev. 2011, 23, 444-467. [CrossRef]

7. Terenina, E.; Fabre, S.; Bonnet, A.; Monniaux, D.; Robert-Granie, C.; Sancristobal, M.; Sarry, J.; Vignoles, F.; Gondret, F.; Monget, P. Differentially expressed genes and gene networks involved in pig ovarian follicular atresia. Physiol. Genom. 2016, 49, 67-80. [CrossRef]

8. Cao, R.; Wu, W.J.; Zhou, X.L.; Xiao, P.; Wang, Y.; Liu, H.L. Expression and preliminary functional profiling of the let-7 family during porcine ovary follicle atresia. Mol. Cells 2015, 38, 304-311. [CrossRef]

9. Strasser, A. The role of BH3-only proteins in the immune system. Nat. Rev. Immunol. 2005, 5, 189-200. [CrossRef]

10. Sionov, R.V.; Vlahopoulos, S.A.; Granot, Z. Regulation of Bim in Health and Disease. Oncotarget 2015, 6, 23058-23134. [CrossRef]

11. Hübner, A.; Barrett, T.; Flavell, R.A.; Davis, R.J. Multisite Phosphorylation Regulates Bim Stability and Apoptotic Activity. Mol. Cell 2008, 30, 415-425. [CrossRef] [PubMed]

12. Ewings, K.E.; Kathryn, H.M.; Wiggins, C.M.; Wickenden, J.A.; Kathryn, B.; Rebecca, G.; Kurt, D.; Eileen, W.; Cook, S.J. ERK1/2-dependent phosphorylation of BimEL promotes its rapid dissociation from Mcl-1 and Bcl-xL. EMBO J. 2014, 26, 2856-2867. [CrossRef] [PubMed]

13. Wang, Y.; Zeng, S. Melatonin Promotes Ubiquitination of Phosphorylated Pro-Apoptotic Protein Bcl-2-Interacting Mediator of Cell Death-Extra Long (BimEL) in Porcine Granulosa Cells. Int. J. Mol. Sci. 2018, 19, 3431. [CrossRef] [PubMed]

14. Luciano, F.; Jacquel, A.; Colosetti, P.; Herrant, M.; Cagnol, S.; Pages, G.; Auberger, P. Phosphorylation of Bim-EL by Erk1/2 on serine 69 promotes its degradation via the proteasome pathway and regulates its proapoptotic function. Oncogene 2003, 22, 6785-6793. [CrossRef]

15. Ley, R.; Balmanno, K.; Hadfield, K.; Weston, C.; Cook, S.J. Activation of the ERK1/2 signaling pathway promotes phosphorylation and proteasome-dependent degradation of the BH3-only protein, Bim. J. Biol. Chem. 2003, 278, 18811-18816. [CrossRef]

16. Geissler, A.; Haun, F.; Frank, D.O.; Wieland, K.; Simon, M.M.; Idzko, M.; Davis, R.J.; Maurer, U.; Borner, C. Apoptosis induced by the fungal pathogen gliotoxin requires a triple phosphorylation of Bim by JNK. Cell Death Differ. 2013, 20, 1317-1329. [CrossRef]

17. Beth, L.; Sangita, S.; Guido, K. Bcl-2 family members: Dual regulators of apoptosis and autophagy. Autophagy 2008, 4, 600-606. 
18. Ley, R.; Ewings, K.E.; Hadfield, K.; Cook, S.J. Regulatory phosphorylation of Bim: Sorting out the ERK from the JNK. Cell Death Differ. 2005, 12, 1008-1014. [CrossRef]

19. Bonora, M.; Wieckowsk, M.R.; Chinopoulos, C.; Kepp, O.; Kroemer, G.; Galluzzi, L.; Pinton, P. Molecular mechanisms of cell death: Central implication of ATP synthase in mitochondrial permeability transition. Oncogene 2015, 34, 1475-1486. [CrossRef]

20. Wu, Y.; Wang, Y.; Liu, Q.; Zhu, L.J.; Gao, H.; Cui, M.; Liu, J.; Zhao, P.; Liu, J.; Chen, L. Conserved microRNA mediates heating tolerance in germ cells versus surrounding somatic cells. Rna Biol. 2019, 16, 1494-1503. [CrossRef]

21. Han, Y.; Wang, S.; Wang, Y.; Zeng, S. IGF-1 Inhibits Apoptosis of Porcine Primary Granulosa Cell by Targeting Degradation of BimEL. Int. J. Mol. Sci. 2019, 20, 5356. [CrossRef] [PubMed]

22. Han, Y.; Wang, S.; Lin, L.; Gao, H.; Wang, Y.; Ji, Z.; Zeng, S. Insulin mitigates apoptosis of porcine follicular granulosa cells by downregulating BimEL. Reprod. Biol. 2019, 19, 293-298. [CrossRef] [PubMed]

23. Wang, X.L.; Wu, Y.; Tan, L.B.; Tian, Z.; Liu, J.H.; Zhu, D.S.; Zeng, S.M. Follicle-stimulating hormone regulates pro-apoptotic protein Bcl-2-interacting mediator of cell death-extra long (BimEL)-induced porcine granulosa cell apoptosis. J. Biol. Chem. 2012, 287, 10166-10177. [CrossRef] [PubMed]

24. Jolly, P.D.; Smith, P.R.; Heath, D.A.; Hudson, N.L.; Lun, S.; Still, L.A.; Watts, C.H.; Mcnatty, K.P. Morphological evidence of apoptosis and the prevalence of apoptotic versus mitotic cells in the membrana granulosa of ovarian follicles during spontaneous and induced atresia in ewes. Biol. Reprod. 1997, 56, 837-846. [CrossRef] [PubMed]

25. Li, J.; Gao, H.; Tian, Z.; Wu, Y.; Wang, Y.; Fang, Y.; Lin, L.; Han, Y.; Wu, S.; Haq, I.; et al. Effects of chronic heat stress on granulosa cell apoptosis and follicular atresia in mouse ovary. J. Anim. Sci. Biotechnol. 2016, 7, 57-66. [CrossRef]

26. Lei, K.; Davis, R.J. JNK phosphorylation of Bim-related members of the Bcl2 family induces Bax-dependent apoptosis. Proc. Natl. Acad. Sci. USA 2003, 100, 2432-2437. [CrossRef]

27. Lin, W.; Zhang, Z.; Xu, Z.; Wang, B.; Li, X.; Cao, H.; Wang, Y.; Zheng, S.J. The association of receptor of activated protein kinase C 1(RACK1) with infectious bursal disease virus viral protein VP5 and voltage-dependent anion channel 2 (VDAC2) inhibits apoptosis and enhances viral replication. J. Biol. Chem. 2015, 290, 8500-8510. [CrossRef]

28. Kong, D.; Gong, L.; Arnold, E.; Shanmugam, S.; Fort, P.E.; Gardner, T.W.; Abcouwer, S.F. Insulin-like growth factor 1 rescues R28 retinal neurons from apoptotic death through ERK-mediated BimEL phosphorylation independent of Akt. Exp. Eye Res. 2016, 151, 82-95. [CrossRef]

29. Tilly, J.L.; Tilly, K.I.; Perez, G.I. The genes of cell death and cellular susceptibility to apoptosis in the ovary: A hypothesis. Cell Death Differ. 1997, 4, 180-187. [CrossRef]

30. Mann, J.J.; Fraker, P.J. Zinc pyrithione induces apoptosis and increases expression of Bim. Apoptosis 2005, 10, 369-379. [CrossRef]

31. Akiyama, T.; Dass, C.R.; Choong, P.F.M. Bim-targeted cancer therapy: A link between drug action and underlying molecular changes. Mol. Cancer Ther. 2009, 8, 3173-3180. [CrossRef] [PubMed]

32. Zhang, H.; Zuo, Z.; Lu, X.; Wang, L.; Wang, H.; Zhu, Z. MiR-25 regulates apoptosis by targeting Bim in human ovarian cancer. Oncol. Rep. 2012, 27, 594-598. [CrossRef]

33. Shinjyo, T.; Kuribara, R.; Inukai, T.; Hosoi, H.; Kinoshita, T.; Miyajima, A.; Houghton, P.J.; Look, A.T.; Ozawa, K.; Inaba, T. Downregulation of Bim, a proapoptotic relative of Bcl-2, is a pivotal step in cytokine-initiated survival signaling in murine hematopoietic progenitors. Mol. Cell. Biol. 2001, 21, 854-864. [CrossRef] [PubMed]

34. Elke, D.B.; Bos, T.J.; Frans, S.; Els, V.V.; Eline, M.; Lieven, T.; Peter, A.; Helena, J.W.; Karin, V. IGF-1 suppresses Bim expression in multiple myeloma via epigenetic and posttranslational mechanisms. Blood 2010, 115, 2430-2440.

35. Hansen, P.J. Effect of heat stress on mammalian reproduction. Philos. Trans. R. Soc. Lond. 2009, 364, 3341-3350. [CrossRef] [PubMed]

36. Ozawa, M.; Tabayashi, D.; Latief, T.A.; Shimizu, T.; Oshima, I.; Kanai, Y. Alterations in follicular dynamics and steroidogenic abilities induced by heat stress during follicular recruitment in goats. Reproduction 2005, 129, 621-630. [CrossRef] [PubMed] 
37. Shimizu, T.; Ohshima, I.; Ozawa, M.; Takahashi, S.; Tajima, A.; Shiota, M.; Miyazaki, H.; Kanai, Y. Heat stress diminishes gonadotropin receptor expression and enhances susceptibility to apoptosis of rat granulosa cells. Reproduction 2005, 129, 463-472. [CrossRef]

38. Yao, F.; Chang-Jiu, H.; Peng-Yun, J.; Zhi-Yong, Z.; Xiu-Zhi, T.; Feng, W.; Dun-Xian, T.; Guo-Shi, L. Effects of melatonin on the proliferation and apoptosis of sheep granulosa cells under thermal stress. Int. J. Mol. Sci. 2014, 15, 21090.

39. Mustafi, S.B.; Chakraborty, P.K.; Dey, R.S.; Raha, S. Heat stress upregulates chaperone heat shock protein 70 and antioxidant manganese superoxide dismutase through reactive oxygen species (ROS), p38MAPK, and Akt. Cell Stress Chaperones 2009, 14, 579-589. [CrossRef]

40. Cui, M.S.; Fan, Y.P.; Wu, Y.; Hao, Z.D.; Liu, S.; Chen, X.J.; Zeng, S.M. Porcine cumulus cell influences ooplasmic mitochondria-lipid distributions, GSH-ATP contents and calcium release pattern after electro-activation. Theriogenology 2009, 71, 412-421. [CrossRef]

41. Lu, X.; Kambe, F.; Cao, X.; Yamauchi, M.; Seo, H. Insulin-like growth factor-I activation of Akt survival cascade in neuronal cells requires the presence of its cognate receptor in caveolae. Exp. Cell Res. 2008, 314, 342-351. [CrossRef] [PubMed]

42. Harada, H.; Quearry, B.; Ruizvela, A.; Korsmeyer, S.J. Survival factor-induced extracellular signal-regulated kinase phosphorylates BIM, inhibiting its association with BAX and proapoptotic activity. Proc. Natl. Acad. Sci. USA 2004, 101, 15313-15317. [CrossRef] [PubMed]

43. Willis, S.N.; Fletcher, J.I.; Kaufmann, T.; Delft, M.F.V.; Huang, D.C.S. Apoptosis Initiated When BH3 Ligands Engage Multiple Bcl-2 Homologs, Not Bax or Bak. Science 2007, 315, 856-859. [CrossRef] [PubMed]

44. Moustafa-Kamal, M.; Gamache, I.; Lu, Y.; Li, S.; Teodoro, J.G. BimEL is phosphorylated at mitosis by Aurora A and targeted for degradation by betaTrCP1. Cell Death Differ. 2013, 20, 1393-1403. [CrossRef] [PubMed]

(C) 2020 by the authors. Licensee MDPI, Basel, Switzerland. This article is an open access article distributed under the terms and conditions of the Creative Commons Attribution (CC BY) license (http://creativecommons.org/licenses/by/4.0/). 